\title{
FINANCIAL OMBUDSMAN: TOWARDS AN EFFECTIVE CUSTOMERS RIGHTS PROTECTION IN UKRAINE
}

\author{
Roksolana Khanyk-Pospolitak ${ }^{1}$ \\ $\mathrm{Ph} \mathrm{D}$ in Law, Head of Private Law Department, \\ Faculty of Law, National University 'Kyiv-Mohyla Academy' \\ (Kyiv, Ukraine)
}

doi.org/10.33327/AJEE-18-2.4-a000019

\begin{abstract}
Summary: 1. Introduction. - 2. Existing Extrajudicial Mechanisms for Rights Protection of Financial Services Consumers in Ukraine. - 3. World Models of the Financial Ombudsman as the Basis for the Financial Ombudsman Institute in Ukraine. - 4. The Genesis of the Concept of a Financial Ombudsman in Ukraine. - 5. Current Legal, Institutional and Theoretical Prerequisites for Establishing an Institute of Financial Ombudsman in Ukraine. - 6. Preparation of the Draft Law of Ukraine 'On the Institute of a Financial Ombudsman'. - 7. Compliance of the Draft Law of Ukraine 'On the Institute of a Financial Ombudsman' with the Principles of the Directive on Consumer ADR. - 8. Conclusions.
\end{abstract}

This article explores the prerequisites and prospects for introducing the Financial Ombudsman Office in Ukraine as an institute for alternative (extrajudicial) resolution of disputes between consumers and financial service providers. Particular attention is paid to the analysis of the draft law on the establishment of the Financial Ombudsman in Ukraine. Considering the existing mechanisms of alternative dispute resolution in Ukraine and the possibility of their application to the issues of financial services consumers' rights protection, the historical retrospective of the establishment of the Financial Ombudsman institute in Ukraine is considered. The author analyses the legal, institutional and theoretical prerequisites for the implementation of one of the Financial Ombudsman models operating in other countries. The focus is on the analysis of the compliance of the draft law on the establishment and operation of the institute with the principles set out in Directive 2013/11 on consumer ADR. At the same time, it is stated why one or another structure of the legal regulation of the establishment and activity of the Financial Ombudsman Office in Ukraine was chosen. The author, as one of the experts involved in the drafting of the law, concludes that, despite the compliance of the draft law with the European principles of

1 Note. The author of this article was an expert during investigation and preparation of the draft law 'On the Financial Ombudsman Office' of the USAID project 'Transformation of Financial Sector' <https:// www.facebook.com/FSTProject/ > accessed 2 September 2019. 
the $A B C$, there is, unfortunately, no prospect of its adoption as a legal basis for setting up a Financial Ombudsman Office in Ukraine at the moment and in the coming year, and analyses the causes.

Keywords: ADR, extrajudicial dispute resolution, Financial Ombudsman, consumer protection.

\section{INTRODUCTION}

According to court statistics of Ukraine, 3.8 million cases and materials were submitted to local and appellate courts in 2018, including nearly 40,000 cases, which were not reviewed by liquidated courts, and were submitted to new appellate courts. ${ }^{2}$ Although the level of trust in the courts in Ukraine has increased in recent years, it remains low. ${ }^{3}$ This state of affairs is not beneficial for the speedy and effective resolution of disputes, and therefore to the realization of the principle of accessibility of justice. World experience has long demonstrated that in such cases it is necessary to introduce effective mechanisms for alternative (extrajudicial) dispute resolution.

Article 124 of the Constitution of Ukraine 4 provides for the possibility of securing a mandatory pre-trial settlement of the dispute at the level of law. However, pre-trial dispute settlement and alternative (extrajudicial) means of dispute resolution are not identical concepts. ${ }^{5}$

A number of international and national acts emphasize the need to create a consumer protection system. In particular, in the Action Plan for 2015-2017 of the Council of Europe in the aspect of Effective Functioning and Organization of the Judicial System, the priority is to create a system of alternative dispute resolution. ${ }^{6}$ Similar priorities and expectations are set by the Council of Europe Action Plan for Ukraine for 2018-2021. ${ }^{7}$ The Strategy for Reformation of the Judiciary, Justice and Related Legal Institutions for 2015-2020, approved by the Decree of the President of Ukraine on 20 May 20 2015 , indicates the imperfection of procedural instruments for the protection of the rights and interests of persons, including an underdeveloped system of alternative dispute resolution methods (paragraph 3). Therefore there is a need to expand ways of alternative (extrajudicial) dispute settlement (paragraph 5.4). ${ }^{8}$

2 The Judiciary of Ukraine. Data Review on the Administration of Justice in 2018, p. $2<$ https://court.gov. ua/inshe/sudova_statystyka/analit_rewiew_18> accessed 10 June 2019.

3 According $\mathrm{t}$ o the results of the second $\mathrm{n}$ ationwide survey of the population of Ukraine on trust in the judiciary, judicial reform and attitude to corruption, conducted in October 2018 by USAID 'New Justice' Program, the level of trust increased from 5\% in 2015 to $16 \%$ in $2018</ C$ :/Users/User/ Downloads/1_NJ_October_2018_SurveyPublic_Result_UKR.pdf> accessed 10 June 2019.

4 The Constitution of Ukraine <https://zakon.rada.gov.ua/laws/show/254\%D0\%BA/96-\%D0\%B2\%D1\% $80>$ accessed 10 June 2019.

5 R Khanyk-Pospolitak, “Prejudicial”, "Alternative”, "Extrajudicial” Regulation/Ajudication of Private Law Disputes: Correlation of the Notions' (“Dosudove", "alternatyvne", "pozasudove" vrehuliuvannia/ vyrishennia pryvatnopravnyh sporiv; spivvidnishennia poniat”) (2019) 1 Enterpreneurship, Economy and Law 38.

6 Government portal. Cooperation with the Council of Europe. <https://www.kmu.gov.ua/ua/diyalnist/ yevropejska.../spivrobitnictvo-z-radoyu-yevropi> accessed 10 June 2019.

7 Ehe Council of Europe. Action Plan for Ukraine for 2018-2021 <rm.coe.int/coe-action-plan-for-ukraine2018-2021-ukr/1680925bec > accessed 10 June 2019

8 The strategy for the Reform of the Judiciary, Judicial Procedure and Related Legal Institutions for 2015-2020. The legislation of Ukraine. Official site of the Verkhovna Rada of Ukraine <https://zakon.rada.gov.ua/laws/show/276/2015> accessed 10 June 2019. 


\section{EXISTING EXTRAJUDICIAL MECHANISMS FOR RIGHTS PROTECTION OF FINANCIAL SERVICES CONSUMERS IN UKRAINE}

The financial market plays an important role in the development of any state. The expansion of financial services to consumers is also increasing day by day. That is why there is an increase in the number of consumer appeals to the court or the state regulator, which is currently the National Commission for the State Regulation of Financial Services Markets. This commission provides state regulation in the sphere of financial services markets in case of failure to provide or improper provision of financial services and create conditions for efficient and transparent functioning of non-banking financial services markets.

However, according to the USAID 'Financial Sector Transformation Survey', almost half of Ukrainians, namely $45 \%$, do not know where to go in order to resolve disputes that arise with financial institutions, and another $78 \%$ of Ukrainians do not want to go anywhere at all in case of disputes with financial institutions. ${ }^{9}$

This state of affairs is caused by the actual absence of mechanisms for alternative (extrajudicial) dispute resolution in this area. Moreover, the mechanisms that do exist are not widely used.

In particular, at present, there are only two existing methods of ADR in the field of protection of the rights of financial services consumers - the Ukrainian Insurance Ombudsman ${ }^{10}$ and the Appeal Commission of the Ukrainian Federation of Insurance ${ }^{11}$ (UFI). In both cases, the underwriter who considers his/her rights and interests violated may contact the Ukrainian Insurance Ombudsman or the UFI Directorate free of charge in the prescribed form with a complaint against the company. However, the number of persons who can use ADR data is limited, as the Ukrainian Insurance Ombudsman or the Appeals Commission only deals with complaints about members of this system. And thus, little is known about ADR data in the financial market.

Common practices in the world of ADR are mediation and arbitration. However, in Ukraine it is not possible to apply them to protect the rights of consumers of financial services. The reasons for this are:

1) The lack of legal regulation of this institute hinders the spread of mediation. Despite numerous attempts, none of the draft laws (the latest of which was No. 3665 of 17 December $2015^{12}$ ) was adopted by the Verkhovna Rada of Ukraine.

2) Unlike mediation, arbitration in Ukraine is settled. This is the only way of ADR in Ukraine, which is currently legislated in the special Law of Ukraine 'On Arbitration Courts' of 2004. However, the jurisdiction of arbitration tribunals does not extend to consumer protection cases under Section 14, Art. 6 of this Law. ${ }^{13}$ It should be noted, though, that at the time of adoption of this Law, the jurisdiction of arbitration tribunals did extend to protect the consumers' rights, including the rights of financial services consumers. However, due to the failure of particular arbitration courts to respect the

9 Who is a Financial Ombudsmen and What Does He Do? <http://suddya.com.ua/news/zvernit-uvagu/ hto-takii-finansovii-ombudsmen-i-cim-vin-zaimatimetsa> accessed 3 September 2019.

10 The Ukrainian Insurance Ombudsman. Official Site < http://ombudsman.ua/> accessed 10 June 2019.

11 For Consumers of Insurance Services. Official Site of the Ukrainian Federation of Insurance < http:// www.ufu.org.ua/ua > accessed 10 June 2019.

12 This draft law had the greatest chance of parliamentary approval. However, in February 2019, this draft law failed to get the required number of votes for final adoption.

13 The Law of Ukraine 'On Arbitration Tribunals' < https://zakon.rada.gov.ua/laws/show/1701-15> accessed 10 June 2019 
principle of impartiality (in practice they were also called 'pocket courts' because they solved cases solely for the benefit of one party which was not the consumer), this category of cases was removed from the jurisdiction of these courts in $2011 .^{14}$

\section{WORLD MODELS OF THE FINANCIAL OMBUDSMAN AS THE BASIS FOR THE FINANCIAL OMBUDSMAN INSTITUTE IN UKRAINE}

The Financial Ombudsman Institute has already been successfully established in more than 40 countries: Armenia, Australia, the United Kingdom, Poland, the Netherlands, Italy, Canada, Belgium, Switzerland, Sweden, Denmark, France, Spain, Latvia, Lithuania, etc. ${ }^{15}$ The institute has different names in different states, ${ }^{16}$ but the essence and the purpose of such an institution are solely to resolve the dispute between consumers and financial service providers to improve the quality of consumer confidence in the financial services market.

Currently, there are two models of the Financial Ombudsman Institute in the world: the German one and the British.

The main features of the German system are the following: the institute operates in the banking or other (e.g. insurance ombudsman ${ }^{17}$ ) sector; the ombudsman is one; funded by the banks or another association at which it is established; the ombudsman is appointed by the Board of the German Banks Union; the ombudsman only deals with consumer complaints; the ombudsman's decision is binding to the parties of the dispute if the amount of the dispute is under EUR 10,000. ${ }^{18}$

The UK Financial Ombudsman Institute, known as the British Model, is funded mainly by the state and partly by financial institutions, unlike in the German system. The legal status of the ombudsman is enshrined in a special 'Financial Services and Markets Act, ${ }^{19}$ that extends to the entire financial services market. The Office of the British Ombudsman is one, but several ombudsmen usually specialize in particular areas of the industry, such as insurance, investment, banking, financial companies,

14 The explanatory note to the draft law, which amended the Law of Ukraine 'On Arbitration Courts' in 2011, states that 'recently business entities, especially in the field of banking and insurance services, when concluding contractual relations with consumers have been actively practicing a kind of "imposition" of an agreement clause about consideration of the case in arbitration courts (the so-called arbitration clause or arbitration agreement)' < w1.c1.rada.gov.ua/pls/zweb2/webproc34?id=\&pf3511=38239\&pf35401. > accessed 10 June 2019

15 O Zaitseva, 'Ombudsman in Financial Sphere: Will he be Able to Protect the Rights of Ukrainians? <https://gurt.org.ua/articles/19820/?order=comments> accessed 3 September 2019; 'Who is a Financial Ombudsmen and What Does He Do?' <http://suddya.com.ua/news/zvernit-uvagu/hto-takiifinansovii-ombudsmen-i-cim-vin-zaimatimetsa > accessed 3 September 2019.

16 For example, in Italy the services of an ombudsman are used to resolve disputes in the banking sector, in Germany there is an insurance ombudsman, in France - the Ombudsman of the Financial Markets Agency. In some countries, such mediation mechanisms apply to the entire financial sector: the UK Financial Sector Ombudsman, the Danish Financial Complaints Institute. Another option is setting up a dedicated body to handle all consumer complaints, related not only to the financial sector, for example, the Swedish National Consumer Complaints Council, the Lithuanian State Consumer Protection Agency, Czech Financial Arbitrator in the Czech Republic, Financial System Mediator in Armenia, Financial Arbitration Board in Hungary.

17 The Insurance Ombudsman Association <https://www.versicherungsombudsmann.de/welcome/> accessed 10 June 2019.

18 The ombudsman scheme of the German private commercial banks <https://bankenverband.de/media/ publikationen/Verfahrensordnung_Ombudsmann_June2015_2c_engl.pdf.> accessed 10 June 2019.

19 Financial Services and Markets Act $2000<$ https://www.legislation.gov.uk/ukpga/2000/8/contents> accessed 10 June 2019 
non-governmental pension insurance. ${ }^{20}$ Complaints about the actions or omissions of financial institutions are resolved first by reconciling the parties. ${ }^{21}$

\section{THE GENESIS OF THE CONCEPT OF A FINANCIAL OMBUDSMAN IN UKRAINE}

The process of establishing the Financial Ombudsman Institute in Ukraine has a long history. The legal basis for its foundation, activity and search for a legal model has been underway since 2008. The draft law on the implementation of the Financial Ombudsman Service in Ukraine, which was developed by the Blue Ribbon Centre with the support of the United Nations and the EU, was based on the British model, as stated by the developers themselves. ${ }^{22}$ However, this draft law was never registered with the Verkhovna Rada of Ukraine.

The draft law 'On Amendments to Some Legislative Acts of Ukraine Regarding the Establishment of a System for Financial Services Consumers Protection in the Financial Markets of Ukraine, proposed by the Deputy Yu. Polunieiev in 2011, did not clearly determine which legal model was proposed for the institute, ${ }^{23}$ since it only outlined the creation of the institute, without specifying such important details as the requirements for the candidate of a financial ombudsman, the procedure of creation and his competence.

Further, the attempt to introduce the Financial Ombudsman Institute was made in the banking system. In particular, the Independent Banking Association of Ukraine (IBAU) in 2013 proposed a German model for reference.24 This model, as noted above, is characterized by the fact that it is limited to only one sector which is the banking sector, that is, it was created under IBAU and had to be financed by the contributions of members of the association. However, this attempt was unsuccessful, and the Institute of Financial Ombudsman in the banking sector did not start working in Ukraine.

Currently, the draft law 'On the Institute of the Financial Ombudsman'25 has been registered in the Verkhovna Rada of Ukraine (registration number 8055 of 22 February 2018). It is based on the British model, since the order of its creation and activity is planned to be regulated at the level of the Law. This institute is universal for the whole financial services market and its financing will be provided at the expense of market participants.

20 Official site. Financial Ombudsmen Service < https://www.financial-ombudsman.org.uk/about/index. html; > accessed 10 June 2019.

21 R Khanyk-Pospolitak, 'Financial Ombudsman: Perspectives of Implementation in Ukraine' in OS Zakharova, IO Izarova (eds), The European Standards of Rights Protection in Civil Law: Test of Time (materials of international scientific and practical conference, Kyiv, Dakor 2014).

22 International Analysts: Ukrainian Consumers will Be Assisted by Financial Ombudsman <http:// zhvaniya.com/ua/print_art/14668/> accessed 3 September 2019.

23 Draft Law 'On Amendments to Some Legislative Acts of Ukraine Regarding the Establishment of a System for Financial Services Consumers Protection in the Financial Markets of Ukraine' <http:// search.ligazakon.ua/1_doc2.nsf/link1/JF7EI00I.html> accessed 10 June 2019.

24 Bankers propose to set up an institution of financial ombudsman independent from the authorities in Ukraine <https://tyzhden.ua/News/90790> accessed 3 September 2019; NABU Statute <http://www. nabu.com.ua/ukr/about/statute/> accessed 10 June 2019.

25 Draft Law 'On the Institute of the Financial Ombudsman'. Official Site of the Verkhovna Rada of Ukraine <http://w1.c1.rada.gov.ua/pls/zweb2/webproc4_2?pf3516=8055\&skl=9> accessed 10 June 2019. 


\section{CURRENT LEGAL, INSTITUTIONAL AND THEORETICAL PREREQUISITES FOR ESTABLISHING AN INSTITUTE OF A FINANCIAL OMBUDSMAN IN UKRAINE}

As noted above, for the first time an attempt has been made to develop an effective system for protecting the rights of financial services consumers in Ukraine. In order to improve the protection of the rights of financial services consumers in Ukraine, a number of legal acts were adopted, in particular: The Concept of the State Policy in the Field of Consumer Rights Protection for the Period up to $2020^{26}$, approved by the Decree No. 217 of the Cabinet of Ministers of Ukraine (hereinafter - the CMU) on 29 March 2017; the Strategy for Reforming the System of Consumer Rights Protection in the Markets of Financial Services for 2012-2017, approved by the CMU Decree No. 867-p of 31 October 2012, ${ }^{27}$ Comprehensive Program for the Development of the Financial Sector of Ukraine for up to 2020, approved by the Resolution No. 391 of the National Bank of Ukraine Board of 18 June 2015, ${ }^{28}$ the draft law 'On Amendments to Certain Legislative Acts of Ukraine on Improving the Protection of Financial Services Consumer Rights' (registration number 2456-д of 29 December 2015). ${ }^{29}$

All these documents state that one of the main tasks is to create the conditions for an effective alternative for the regulation of consumer disputes, in particular, by setting up a financial ombudsman institution for the extrajudicial settlement of disputes between the financial sector participants and consumers of financial services in Ukraine.

Among the international documents and studies of international organizations that have become the basis for the development of national legislation in individual countries where such an institute already exists, and which were also taken into account by Ukraine in drafting law 8055, there are: Good Practices for Financial Consumer Protection, 2017 Edition, ${ }^{30}$ 'Resolving Disputes between Consumers and Financial Business: Fundamentals for a Financial Ombudsman. A Practical Guide Based on Experience in Western Europe ${ }^{31}$, 'Consumer Protection and Financial Literacy Lessons from Nine Country Studies,' ${ }^{32}$ etc.), 'G20 High-Level Principles On Financial Consumer Protection' (2011),,33 Directive 2013/11/EU of the European Parliament and of the Council of 21 May 2013 on alternative dispute resolution for consumer disputes and amending Regulation (EC) No. 2006/2004 and Directive 2009/22/EC (Directive on consumer ADR.

The existing institutional infrastructure in the system of protection of the rights of financial services consumers is also a prerequisite for the establishment of such an

26 The Concept of the State Policy in the Field of Consumer Rights Protection for the Period up to 2020 <https://zakon.rada.gov.ua/laws/show/983-2017-\%D1\%80> accessed 10 June 2019.

27 The Strategy for Reforming the System of Consumer Rights Protection in the Markets of Financial Services for 2012-2017< https://zakon.rada.gov.ua/laws/show/867-2012-\%D1\%80> accessed 10 June 2019.

28 Comprehensive Program for the Development of the Financial Sector of Ukraine for up to 2020 <https://zakon.rada.gov.ua/laws/show/v0391500-15> accessed 10 June 2019.

29 Draft Law 2456-д <http://w1.c1.rada.gov.ua/pls/zweb2/webproc4_1?pf3511=57617> accessed 10 June 2019.

30 Official site of the World Bank <https://www.worldbank.org/en/topic/financialinclusion/brief/2017good-practices-for-financial-consumer-protection> accessed 10 June 2019.

31 Official site of the World Bank <http://documents.worldbank.org/curated/en/169791468233091885/apractical-guide-based-on-experience-in-western-Europe > accessed 10 June 2019.

32 Official site of the World Bank <http://www.worldbank.org/en/topic/financialinclusion/publication/ consumer-protection-and-financial-literacy-lessons-from-nine-country-studies $>$ accessed 10 June 2019.

33 G20-OECD Task Force on Financial Consumer Protection <http://www.oecd.org/finance/financialeducation/g20-oecd-task-force-financial-consumer-protection.htm> accessed 10 June 2019. 
institution as a financial ombudsman. Currently, the special Central Executive Body which implements the state policy in the sphere of state control over the observance of the legislation on consumer protection in Ukraine is the State Service for Food Safety and Consumer Protection. It is worth noting right away that the powers of this body, in accordance with Art. 27 of the Law of Ukraine 'On Consumer Protection' ${ }^{34}$ do not cover the protection of the financial services consumers' rights.

At the same time, the current regulations do not contain a clearly defined list or system of state bodies in the sphere of protection of the financial services consumers' rights. Their scope can be determined from the legislation that provides for the authorities that regulate the financial services markets..$^{35}$ In particular, it is the National Bank of Ukraine, the National Securities and Stock Market Commission and the National Commission for the State Regulation of Financial Services Markets.

Such a 'Trojan' system of state bodies does not allow consumers to identify which of these bodies to complain about the protection of their violated rights.

In addition, according to the legislation governing the activity of these bodies, their competence does not include the settlement of disputes between consumers and financial services providers. Thus, according to the provisions of the Law of Ukraine 'On Appeals of Citizens, ${ }^{36}$ consumers can file complaints to these bodies, but this does not lead to a resolution of the dispute.

Therefore, currently there is only one possible way to resolve the dispute, which is to go to court, which significantly complicates the protection of consumer rights.

The necessity of introducing an alternative (extrajudicial) resolution of disputes in the field of financial services, namely the Institute of Financial Ombudsman, is insisted upon by domestic scientists. At the same time, their views differ. In particular, O. Slobodian points to the need to develop an effective legal model of the Commissioner for the Protection of Financial Services Consumer Rights in view of the existing system of state bodies. ${ }^{37} \mathrm{I}$. Bezzub points out the same, stating that the establishment of the institute of a financial ombudsman, who will act as a kind of arbiter between the consumer and the financial institution and assist in the settlement of disputes peacefully, will create an effective alternative to the statejudicial system. ${ }^{38}$

I.G. Britchenko and V.S. Stoyka point out that the creation of financial ombudsman institute will improve the quality of financial market regulation, increase the level of public confidence in financial institutions, strengthen financial discipline, reduce the

34 The Law of Ukraine 'On Consumers' Rights Protection' <https://zakon.rada.gov.ua/laws/show/102312\#n544> accessed 10 June 2019.

35 The Law of Ukraine 'On the National Bank of Ukraine' <https://zakon.rada.gov.ua/laws/show/679-14> accessed 10 June 2019; The Law of Ukraine 'On Financial Services and State Regulation of Financial Services Markets'. < https://zakon.rada.gov.ua/laws/show/2664-14> accessed 10 June 2019; The Law of Ukraine 'On Securities and Stock Market' < https://zakon.rada.gov.ua/laws/show/3480-15> accessed 10 June 2019.

36 The Law of Ukraine 'On Appeals of Citizens'. Official Site of the Verkhovna Rada of Ukraine < https:// zakon.rada.gov.ua/laws/show/393/96-\%D0\%B2\%D1\%80> accessed 10 June 2019.

37 O Slobodian, 'Financial Ombudsman: in search of a legal model' ('Finansovyi ombudsmen: v poshukah pravovoi modeli') (2015) 1 Journal of Law < http://periodicals.karazin.ua/jls/article/view/1641> accessed 3 September 2019.

38 I Bezzub, 'What Kind of a Financial Ombudsman Does Ukraine Need: the European Experience' ('Yakyi finansovyi ombudsmen potriben Ukraini: yevropeiskyi dosvid') <http://nbuviap.gov.ua/index. php?option=com_content\&view=article\&id=3630:yakij-finansovij-ombudsmen-potriben-ukrajinievropejskij-dosvid\&catid=8\&Itemid=350> accessed 3 September 2019. 
burden on the judiciary and increase the transparency and openness of the financial market. ${ }^{39}$ According to N.V. Sachasov, the existence of financial ombudsman can have positive effects on the financial security of financial institutions. ${ }^{40}$

Therefore, the vast majority of scholars agree on the need for a financial ombudsman institute and the adoption of a special law. In particular, this act should regulate the legal, financial and organizational principles of the system of settlement of complaints by financial services consumers against financial service providers, the procedure of formation and legal status of the financial ombudsman service. ${ }^{41}$

\section{PREPARATION OF THE DRAFT LAW OF UKRAINE 'ON THE INSTITUTE OF A FINANCIAL OMBUDSMAN'}

Draft law No. 8055, registered within the Verkhovna Rada of Ukraine, was designed to improve the relationship between financial services consumers and financial service providers in Ukraine, as well as to increase the confidence in the financial services market.

This was preceded by considerable preparatory work and large-scale research carried out within the framework of the Financial Sector Transformation project.

Firstly, the experience has been learned, including the specificities of legislative regulation of the activities of similar institutions in most countries that are a part of The International Network of Financial Services Ombudsman Schemes (INFO Network), ${ }^{42}$ including the United Kingdom, Germany, France, Poland, and Armenia. This helped to select the legal model of the financial ombudsman in Ukraine and to take the experience that the state has already received during the period of activity of this institution into account. Among this large number of countries, a great deal of attention was paid to the activities of the Financial Ombudsman in Poland ${ }^{43}$ and Armenia for several reasons.

Poland, as one of our neighbours has, in many ways, a similar legal system. At the same time, it is an EU member state. Therefore, it was possible to take their achievements related to the European standards into account.

Armenia is a former member of the Soviet Union. The introduction of the Institute of the Financial Ombudsman was initiated by the Central Bank of the Republic of Armenia. However, their activity extends to the entire financial services market. Important experience to borrow is the issue of financing the

39 I G Brytchenko, VS Stoyka, 'Creation of an Institute of Financial Ombudsman: International Experience and Perspectives for Ukraine' ('Sozdaniie instituta finansovogo ombudsmena: mezhdunarodnyi opyt I perspektivy dlia Ukrainy') (2017) 1 Problems of Economy < https://dspace.uzhnu.edu.ua/jspui/handle/ lib/13798> accessed 3 September 2019.

40 NV Zachosov, 'Introduction of a Financial Ombudsman Institute in Ukraine: Possible Implications for the Economic Security of Financial Institutions' ('Zaprovadzhennia instytutu finansovoho ombudsmena v Ukraini: imovorni naslidky dlia economichnoi bezpeky finansovyh ustanov') (2016) 1 (44) Academic Review 80.

41 AI Syrota, 'Financial Ombudsman as an Extra-judicial Dispute Resolution System in the Financial Market of Ukraine' ('Finansovyi ombudsmen yak pozasudova systema vrehuliuvannia sporiv na finansovomu rynku Ukrainy') (2013) 4 (63) Scientific Bulletin of the National University of the SFS of Ukraine (Economics, Law) 67.

42 Official site of The International Network of Financial Services Ombudsman Schemes (INFO Network) <http://www.networkfso.org/about-us.html > accessed 10 June 2019.

43 Official site of the Financial Ombudsman (Rzecznik Finansowy) in Poland <https://rf.gov.pl/english> accessed 3 September 2019. 
financial ombudsman in Armenia and also the acceptance of conciliation as the main procedure for resolving the case. ${ }^{44}$

The experience of these two countries was also important in terms of the potential number of employees the office would need in the future, how many applications could be submitted to the financial ombudsman institution and the resources needed to get started.

Secondly, 'The Analysis of the Case Law in Cases Related to the Protection of the Rights of Consumers of Financial Services' $(2014)^{45}$ was conducted and revealed the main contradictions, gaps in the domestic legislation, which lead to the need for consumers to appeal to the court for the protection of their rights.

Thirdly, a number of meetings were held with representatives of financial service providers, ${ }^{46}$ in particular: the Ukrainian Security Federation, the Independent Association of Banks of Ukraine, the League of Insurance Organizations of Ukraine, the Association of Financial Institutions and others. ${ }^{47}$

Fourthly, a number of measures to discuss the draft law were considered, including the international conference 'Protecting the Rights of Financial Services Consumers 2017: A Way to Build Trust' (12 September 2017) ${ }^{48}$ a roundtable 'How to Restore Confidence in the Financial Sector and Protect the Consumer of Financial Services' (16 April 2018), ${ }^{49}$ a roundtable 'How Will the Financial Ombudsman Protect the Consumer of Financial Services (Discussion of draft law No. 8055)' (10 April 2018) ${ }^{50}$ and others.

Fifthly, the draft Law of Ukraine 'On The Business Ombudsman Institute' (registration number 4591 of 5 May 2016) $)^{51}$ was taken into consideration as an institution of alternative dispute resolution in the field of public law, which was founded in 2014 and has developed successfully and quickly over the years and has shown effective work and has gained the trust of business entities.

Thus, as noted above, the draft law No. 8055 is based primarily on the British model, since the procedure for its creation and operation is planned to be regulated at the level of the Law, and this institute will be universal for the entire financial services market, the principal form of activity of which should be the application of the conciliation procedure. $^{52}$

44 Official site of The Office of Financial System Mediator <https://www.fsm.am/en/home/> accessed 3 September 2019.

45 Yu Vitka, V Strahova, R Khanyk-Pospolitak, T Karnauh, 'The Analysis of the Case Law in Cases Related to the Protection of the Rights of Consumers of Financial Services' <http://ekmair.ukma.edu.ua/ handle/123456789/11229> accessed 3 September 2019.

46 It should be noted that the representatives of consumer rights protection organizations were not involved in the process of drafting the law No. 8055 due to objective reasons, in particular, due to the fact that in practice there are none of such organizations in Ukraine.

47 With this, financial service providers believe that their interests have not been considered at all. See 'Who is a Financial Ombudsman and What Does He Do?' (n 9).

48 Protecting the Rights of Financial Services Consumers 2017: A Way to Build Trust <https://www. facebook.com/FSTProject/posts/1983554305224173/ > accessed 3 September 2019.

49 UAIB News, 'Ukrainian and foreign experts analyze draft law on establishment of financial ombudsman' $<$ http://www.uaib.com.ua/news/weekly_news/265578.html> accessed 3 September 2019.

50 NABU roundtable 'How Will the Financial Ombudsman Protect the Consumer of Financial Services' $<$ https://nabu.ua/ua/zasidannya-kruglogo-stolu-na-temu.html> accessed 3 September 2019.

51 Draft Law No. 4591. Official site of the Verkhovna Rada of Ukraine <http://w1.c1.rada.gov.ua/pls/ zweb2/webproc4_1?pf3511=58980> accessed 10 June 2019.

52 This is one of the basic principles of activity of the financial ombudsman, which is explicitly stipulated in item 7 of Art. 4 of the draft law No. 8055. 


\section{COMPLIANCE OF THE DRAFT LAW OF UKRAINE 'ON THE INSTITUTE OF A FINANCIAL OMBUDSMAN’ WITH THE PRINCIPLES OF THE DIRECTIVE ON CONSUMER ADR}

Based on Ukraine's Euro-integration aspirations, Ukraine's commitments under the Association Agreement ${ }^{53}$ regarding the adaptation of national legislation to EU law raise the important question of whether the draft law 8055 meets the principles enshrined in the Directive on Consumer ADR. More specifically, how are the principles of Directive on consumer ADR implemented in the draft law No. 8055?

Regarding the first question, it should be noted that when drafting the law No. 8055, the working group tried to fully comply with the requirements of the Directive on consumer ADR.

However, before analyzing the implementation of the principles of Directive on consumer ADR in draft law No. 8055, it is worth to briefly mention the name of the institute itself. At first, the draft law was called 'On the Financial Ombudsman', but in the course of work it was decided to change its name to 'Financial Ombudsman Institute' because of the following reasons.

Firstly, the financial ombudsman will not act alone, but will be assisted by an entire staff of employees. That is, a financial ombudsman cannot be created as a sole proprietorship or in any other form permitted for the individual in Ukraine, it must be a legal entity.

Secondly, the title of the draft law 'On The Business Ombudsman Institute' was taken into consideration. By parity of reasoning, the name 'The Financial Ombudsman Institute' will be better perceived as something positive.

Returning to the issue of compliance of the draft law 8055 with the Directive on Consumer ADR, we should notice that the Directive on Consumer ADR enshrines 8 universal basic principles of ADR institutions: expertise, independence and impartiality (art. 6), transparency (art. 7), effectiveness (art. 8), fairness (art. 9), liberty (art. 10) and legality (art. 11). Six of these principles, namely legality, independence, transparency, efficiency, impartiality and justice, are explicitly enshrined in Art. 4 of draft law No. 8055 as the basic principles of activity of the Institute of the Financial Ombudsman.

In addition, it should be noted that the principles of independence, impartiality, clarity of scope and powers, accessibility, effectiveness, fairness, transparency and accountability should be basic in the development of the Financial Ombudsman system in accordance with the Guide to setting up a Financial Services Ombudsman Scheme developed by INFO Network's in March 2018. ${ }^{54}$

Article 9 of draft law No. 8055 sets out the basic professional requirements for the financial ombudsman, including higher education in economics, finance or law, impeccable business reputation, professional experience in the field of law or the financial services markets for at least ten years. At the same time, the legislator establishes additional requirements for the person as he/she applies for the position of financial ombudsman, in particular: legal capacity, criminal record, perfect business reputation.

Of course, the last requirement of 'perfect business reputation' is very subjective, but the practice, in particular in the financial sector, has already begun to develop the relevant

53 Association Agreement between Ukraine, on the one part, and the European Union, the European Atomic Energy Community, and their Member States, on the other part <https://zakon.rada.gov.ua/ laws/show/984_011> accessed 10 June 2019.

54 This is one of the basic principles of activity of the financial ombudsman, which is explicitly stipulated in item 7 of Art. 4 of the draft law. 
criteria. Take, for example, the banking sector, where the Law of Ukraine 'On Banks and Banking Activity' (Article 2), the Resolution of the Board of the National Bank of Ukraine 'On Approval of the Regulation on Licensing of Banks' No. 149 of 22 December 2018 (Chapters 6 and 7 of Section II) indicates the criteria for a good business reputation. Therefore, in our opinion, they can be applied by analogy to the financial ombudsman.

In order to ensure the principles of 'independence' and 'impartiality' in the activities of the Financial Ombudsman, as required by the Directive on Consumer ADR, the draft law No. 8055 provides for a number of provisions, in particular:

1) The term of office of the financial ombudsman (Part 9, Article 9). The directive on consumer ADR specifies that the person who will resolve disputes in the order of ADR should be appointed for a term of not less than three years (clause b, Part 3, Article 6). Draft law No. 8055 stipulates that a financial ombudsman should be elected for a term of four years, with the right to be re-elected for the next term. The number of terms is unlimited.

2) The prohibition for anyone to interfere with the activities of the Financial Ombudsman (Part 3, Article 5).

3) The procedure for electing a person to the position of financial ombudsman (Part 9, Article 9, Articles 6, 7 and 8). Draft law No. 8055 provides for a sufficiently complicated election procedure. In particular, as provided for in the Directive on consumer ADR, it should be carried out by a collegiate body which is the supervisory board. The Supervisory Board of the Financial Ombudsman Institution is composed of representatives from the following public authorities, institutions and organizations (associations): 1) one representative from the bodies regulating the markets for financial services (but not more than three persons); 2) one representative from organizations (associations) representing the interests of financial service providers (but not more than four persons); 3 ) one representative from the organizations protecting the rights of consumers of financial services (but not more than four persons).

Members of the Supervisory Board also have special requirements. The Supervisory Board is elected by the Nomination Committee, which is formed by the Ministry of Justice of Ukraine. ${ }^{55}$ We believe that such an approach to the procedure for setting up a Financial Ombudsman's Office is inappropriate and complicated, which may make it impossible to create it in practice. However, it is this procedure that was prescribed after extensive consultation and agreement with financial service providers.

But there is also another practical problem that may make the establishment of a financial ombudsman impossible. The Supervisory Board should be composed of representatives of organizations representing consumers. According to the research conducted by the USAID Financial Sector Transformation Project, ${ }^{56}$ as of August 2018, 26 All-Ukrainian Consumer Protection Organizations were registered in the Unified State Register of Legal Entities, Individual Entrepreneurs and Public Formations, 14 of which listed the protection of the rights of consumers of financial services. However, only 3 were found to be working during the study.

4) The exceptional list of cases of termination of powers of the financial ombudsman (Part 6 of Article 9).

5) The prohibition of combining the position of a financial ombudsman with positions in state or local self-government bodies, political parties, engaging in business activities, having any relation to financial market participants (Article 10).

$55 \quad$ It should be added that at the beginning it was planned to make the procedure for electing the financial ombudsman similar to the election of a business ombudsman, i.e. by the Cabinet of Ministers of Ukraine. 
6) Institute of withdrawal (self-withdrawal) of Financial Ombudsman (Article 22).

7) The procedure for financing the activities of the financial ombudsman institution (Article 13). This point is worth particular attention as, as envisaged by the draft law No. 8055, the financing of the activity of the financial ombudsman institute will be made through contributions to the financing of the activities of the financial ombudsman institute (initial and periodic) and fees for the dispute. The very first component of financing at the expense of financial service providers has caused tremendous resistance on their part. They are not comfortable with the situation where they will receive complaints at the expense of the money they contribute to financing the activities of the Financial Ombudsman ${ }^{.57}$

8) The impossibility within one year after the termination of the powers of the financial ombudsman to be an employee of a professional financial market participant (Part 5, Article 10).

The principles of transparency, effectiveness and equity set out in Articles 7, 8 and 9 of the Directive on Consumer ADR are implemented in the draft law 8055 in the following ways:

- Article 12 enshrines the powers of the financial ombudsman. In our opinion, it should be noted that the Financial Ombudsman may consider a dispute that does not exceed one hundred minimum wages on the day of referral to the Financial Ombudsman's Institution (paragraph 2, Part 5, Article 17) (according to the NBU rate this is EUR 14,000 as of June 2019)..$^{58}$ This amount corresponds to the limits when the court can hear the cases in the simplified procedure, provided for in Art. 274 of the CPC of Ukraine. ${ }^{59}$ This restriction is in line with the practice of the European and INFO Network member countries. For example, in the Republic of Armenia, the amount of an appeal to a financial ombudsman may not exceed ten million Armenian drams or its foreign exchange equivalent amount; ${ }^{60}$ in Poland it is no higher than 50 $000 \mathrm{z} .,{ }^{61}$ in England it is no higher than $£ 350,000 .{ }^{62}$

- Section III sets out in sufficient detail the procedure for handling disputes by the Financial Ombudsman. In this respect, in our opinion, the following should be noted: a) that the consumer has the right to apply for his choice in paper or electronic form; $b$ ) a prerequisite to appeal to a financial ombudsman institution is to appeal to a financial institution that has violated the rights of the consumer of financial services; $c$ ) the lack of necessity to involve a lawyer, etc. It is these elements in the case and not the procedure that is important in terms of the Directive on consumer ADR;

- Article 15 provides for the publication of the annual financial statements checked by the auditor on the official website in the Internet;

- Article 20 establishes a minimum fee for consumers for litigation using financial ombudsman institute service. It should be noted that initially the right to apply for free

57 Who is a Financial Ombudsman and What Does He Do?' (n 9).

58 The National Bank of Ukraine. Official exchange rate of hryvnia against foreign currencies <https:// bank.gov.ua/control/uk/curmetal/detail/currency?period=daily> accessed 3 September 2019.

59 Civil Procedure Code of Ukraine <https://zakon.rada.gov.ua/laws/show/1618-15/stru\#Stru> accessed 10 June 2019.

60 Article 3 of The Republic of Armenia Law On Financial System Mediator <https://www.fsm.am/en/ about-us/legal-acts/> accessed 10 June 2019.

61 Rejestr podmiotów uprawnionych - Polubowne Rozwiązywanie <polubowne.gov.pl/download/other/.../ rejestr_podmiotow.xls> accessed 3 September 2019.

62 Increasing the award limit for the Financial Ombudsman Service <https://www.fca.org.uk/publication/ policy/ps19-08.pdf> accessed 3 September 2019. 
was provided, however, representatives of financial market providers insisted on such a norm that would reduce the possibility of abuse of service of financial ombudsman institute by 'unscrupulous' consumers of financial services. As is well known, this approach is absolutely in line with the Directive on consumer ADR, since the relevant provisions allow for a symbolic fee for accessing ADR institutions;

- Article 23 sets out the term of the case by a financial ombudsman institution, which, as provided for in the Directive on consumer ADR, may not exceed 90 days.

- Articles 30, 31 and 32 stipulate the bindingness of decisions of the financial ombudsman institute, the possibility of appealing such a decision and the enforcement of the decision in the event of the parties to the dispute refusing to execute it voluntarily. It is because of the provisions of these articles of draft law No. 8055 that the principle of legality is immediately implemented, the criteria of which are laid down in Art. 11 of the Directive on consumer ADR, since the consumer always has the right to go to court. The provisions of the Directive on Consumer ADR give states the power to decide whether decisions by ADR institutions are voluntary or binding. Considering the Ukrainian specificity, it was decided to consolidate the principle of binding decision of the financial ombudsman for financial service providers, as the parties may simply ignore and not implement such decisions. However, the representatives of financial service providers strongly disagree with this rule. In their view, this provision is contradictory, violates the equality of the parties, and restricts their constitutional right to apply to court. ${ }^{63}$

\section{CONCLUSIONS}

To sum up, it is worth noting that there is virtually no alternative (extrajudicial) resolution of disputes in the area of protection of financial services consumers in Ukraine today. The means available, such as the Insurance Ombudsman or the UFS Appeal Commission, are neither widely used nor effective.

The Institute of the Financial Ombudsman in Ukraine has been supported and has been ongoing for over 10 years, but has not been successful as of yet.

In Ukraine, it is proposed to introduce various elements of the basic models of this institute, in particular, the German and British. Currently, the draft law of Ukraine 'On the Institute of the Financial Ombudsman' submitted to the VRU is based on the British model, taking into account the best practical experience of the activity of the Financial Ombudsman in the Republic of Poland and Armenia.

This draft law is in line with the European principles, including expertise, independence, impartiality, transparency, effectiveness, fairness, liberty and legality as laid down in the Directive on Consumer ADR, thereby approximating national legislation to the EU standards and facilitating the implementation of the 2014 Association Agreement between Ukraine and the European Union.

However, it should be noted that in the coming year or two, the Institute of Financial Ombudsman in Ukraine will not be introduced due to the difficult political situation in the country, as well as the unwillingness of market participants (financial service providers) to compromise when deciding disputes with their consumers.

63 Resolving Disputes With Banks Without Court: Why Do Ukrainians Need the Financial Ombudsman $<$ https://ukr.segodnya.ua/economics/finance/reshenie-sporov-s-bankami-bez-suda-zachemukraincam-finansovyy-ombudsmen-1117882.html> accessed 3 September 2019; V Volkovskaya, 'Why Does Ukraine Need the Financial Ombudsman' <https://afi.org.ua/articles/viktoriya-volkovskayazachem-ukraine-finansovyy-ombudsmen> accessed 3 September 2019. 